\title{
「ネットワーク型ロボットシステム」 特集について
}

人手による定型業務がつぎつぎとコンピュータ化されて いくことが時代の流れとしてすっかり定着した. しかし， 最近その形態に急激な変化が見られる.メインフレームに よる集中型の形態だけでなく，多数の分散したワークステ ーションによる水平分散型の構成が生まれてきた。いわゆ るダウンサイジングである.これに伴い，ネットワーク技 術がクローズアップされてきている.コンピュータネット ワーク, DTP (Distributed Transaction Processing) な どの概念も生まれた。ネットワークを介して，複数のコン ピュータが協調しながら一連の業務を並列的に処理してい くという考え方は，確かに魅力がある．しかし，同時に多 くの課題を抱え込んだ.

ネットワーク上のデータベースマシンや計算資源はサー バと呼ばれ，これらに対して情報処理の要求を出すマシン やプロセスがクライアントと呼ばれる.このクライアント とサーバが複数存在するために，ある業務プロセスの整合 性を保つことが難しくなる．例えば，あるクライアントの 業務を遂行するための一連のファイルの読み書きをサーバ が行っている途中に, 別のクライアントからの書き込み要 求を受けてしまったような場合，タイミングによって異な つた結果になってしまう。.また，サーバが計算資源の場 合，どのサーバがどのクライアントの依頼を受けたら最も 高い稼働率が得られるのか，というスケジューリング問題 が発生する. さらに厄介なのは，システム障害時の対策で ある. 複数のサーバを巻き込んだ並列トランザクション処 理の最中に通信回線がダウンした場合, どのように復旧し たら良いのか，あるいはサーバの異常を通信を介してどの ように検出し，どのように補機を立ち上げたら良いのか, といったことは，考えたくもないほど複雑怪奇な問題であ る.コンピュータネットワークの世界では，このような問 題が徐々に解決されてきたことによって今日の隆盛を見て いる.

さて，前置きが長くなったが，以上述べた話は全くその ままロボットの世界に持ち込むことができる，いわゆるマ ルチエージェントロボットである，通信の観点を協調する とネットワークロボットと名付けることもできょう. そこ で，本号では「ネットワーク型ロボットシステム」の特集 を組んだ．この特集の動機のひとつには，同名のロボット 学会研究専門委員会の活動がある.そこでゲストエディ夕 として研究専門委員会の委員長である福田敏男氏（名大） と委員の淺間一氏（理研）にご助力をいただき，以下のよ うに構成した。
まず福田敏男氏にネットワーク型ロボットという言葉の 由来を概説していただき，通信を用いたロボットシステム の研究の動向と今後の展望を述べていただいた.

「複数の移動ロボットの協調」では加藤晋氏（筑波大）, 武野純一氏（明大）が，知能ロボットの協調という命題を 冷静に見つめ, その定義及び利点と欠点を解説してくださ った.

「自己増殖ロボットにおける通信と協調制御」では私が自 己増殖ロボットを例にとり，分化と機能発現という観点か らロボットセル間の通信の役割と重要性について述べた。

「ロボットと人間のコミュニケーションと協調」では小林 尚登氏（法政大）が人間をロボットと同レベルの自律オブ ジェクトとして捕らえ，協調作業を遂行するためのコミュ ニケーションの在り方を述べてくださった.

「自律エージェントのコミュニケーション」では石田亨氏 （京大) が，自律的な計算主体であるエージェント間の通信 プロトコルには新しい設計原理が必要であること，及びそ の具体例を分散人工知能分野に照らして解説してくださっ た.

「ロボット集団に扔ける生物的コミュニケーションと協 調動作」では下原勝慧氏（ATR）が，人工生命の分野で研 究されている生物の集団的行動をトピックスとして取り上 げ，集団生物学的な視点からコミュニケーションを論じて くださった

また，講義の欄では吉田裕氏（法政大）が「通信技術と プロトコル」と題し，通信ネットワークの基本構成から説 き起こし，OSI の階層モデルなどの通信プロトコルの基 本を解説してくださった。

さらに本号では事例紹介の欄においても，通信を用いた 協調型ロボットにテーマをしぼり，示唆に富む事例が紹介 されている.

コンピューティングの世界でダウンサイジングが普及し てきているように，ロボットの世界も単機能ロボット群に よる相互通信を介した並列分散処理へと移行するものと思 われる. しかし，魅力的なこのパラダイムを真に実用とな るレベルに実現するには，やはり多くの課題がある．その 解決のためにこれらの記事が読者のお役に立てれば幸いで ある。

最後に，ご多用中にもかかわらず原稿をお寄せいただい た著者の方々に厚く御礼申し上げます。

（市川芳明 （株）日立製作所エネルギー研究所） 